\title{
Causes and Effect of Deterioration in Students' Hall of Resident in Nigeria Tertiary Institution
}

\author{
Ibrahim-Adedeji K.B. \\ Department of Urban and Regional Planning,Lagos State Polytechnic, Ikorodu, Lagos, Nigeria: \\ A Case of ObafemiAwolowo University, Ile-Ife, Osun State
}

\begin{abstract}
Students' housing still remains the major area of concern with increasing in students' population as a result of increasing enrolment into tertiary institution of learning over the years. One of these problem include inadequate infrastructure facilities due to overcrowding, which has indeed met with renewed interest in sourcing and researching the best practicable approach towards providing efficient and supporting academic driven environment. The study aim at examining the causes and effect of deterioration in the students' hall of resident in ObafemiAwolowoUniversity,Ile-Ife, Osun-State, Nigeria, 270 questionnaires were administered in all the nine hall of resident namely Fajuyi hall, Awolowo hall, Angola hall, E.T.F. hall, Post Graduate hall, Sport hall, Alumni hall, Mozambique hall and Moremi hall. Data collected were presented through the use of tables, graphs, photographs and regression analysis. The study revealed that there is a level of dissatisfaction with the poor state and condition of available students' housing facilities, the inadequacy of the existing facilities which has created high level of illegal squatter and occupancy ratio has invariably led to over utilization of the available resources putting the facilities in more deteriorating conditions.
\end{abstract}

Keyword:-Causes and Effect, Deterioration, Students' Hall Of Resident, Nigeria Tertiary Institution

\section{INTRODUCTION}

Housing is a key basic need of every human being just as food and clothing. It is quite fundamental to the welfare, survival and health of man (Onibokun, 1999); (Omole, 2001). Hence, housing is part of the best indicators of a person's standard of living and his place in the society. It reflects the cultural, social and economic values of a society as it is the best physical and historical evidence of civilization in a country (Aluko, 2009) (Jiboye, 2011). The students' housing has been a major area of concern with increasing students' population as a result of increasing interest in the tertiary institution of learning over the years.

The increase instudents' population which has led to various level of deterioration in students' hall of resident, which range from poor state of infrastructure facilities to inadequate/overcrowding, has indeed met with renewed interest in sourcing and researching the best practicable approach towards the enablement and efficient, conducive academic driven environment. It is essential for students' housing to provide the basic infrastructure facility needed by the student. Such facilities include toilets, water supply, electricity, reading room, canteen, buttery, kitchen or kitchenette and a recreation area provision of these facilities in good working order are mostly not always readily available. It is a fairly common occurrence for these facilities to either be unavailable or in a state of disrepair.(Aluko, 2011).

Students' need an effective and conducive facilities in their hall of resident at ObafemiAwolowo University, Ile-Ife. This cannot be overemphasized due to the fact that students are expected to be in a sound state of mind to excel in their various academic pursuits which can be achieved only by a good students' housing system. Since students' hall of residents' provides not only physical protection but also a healthy social and behavioural stability, the productivity of a set of students may not be totally unconnected with their student housing condition. The purpose of this study is therefore to assess the students' hall of resident condition in ObafemiAwolowo University, Ile-Ife with a view to provide information about the causes and effects for policy guidelines towards a functional, efficient, conducive and better housing system within the Nigerian institution of higher learning.

\section{STATEMENT OF THE RESEARCH PROBLEM}

Students' housing condition has always been one of the major challenges facing tertiary institution in Nigeria due to the fact that students admitted exceeding the available facilities provided by the institution's authority. The notable problems facing the housing ranges from insecurities due to growing overcrowding of students which leads to congestion and as a result, mounting to increase pressure on infrastructures, social amenities and rapidly deteriorating environment, the existing housing facilities has increase in pressure because of it shortage of dwelling units whereby as many as fifteen (15) students shares a space allocated to six (6) and 
twenty (20) students' shares a space allocated to twelve (12). In addition, the problems of unsanitary environment mostly lead to the outbreak of diseases and socio disorder.In addition to the problem of dirty and unclean environment coupled with unclean water supply within the hall of resident has really affected the students in so many ways. However, for a more improved in the students' hall of resident, various problems need to be tackled to achieve success in various fields of endeavor. Some of the questions that we try to examine are: What is the total carrying capacity of rooms in each of the students housing? What is the number of the rooms in each students' hall of resident? What is the level of infrastructure facilities in the students' hall of residence? What is the present state of the student housing facilities? And who are the authorities responsible for managing the students' house?

The significant and benefit of examining the causes and effect of deterioration in the students' hall of resident in the University, cannot be overemphasized. Though cost of transportation as well as proximity to school area is not usually a major determinant to students' residing on campus. The University therefore provides priority to both the first year students and final year students' who will be writing project when allocating hall of resident. This study is therefore carried out to examine the causes and effect of deterioration in the students' hall of residence.

\section{REVIEW OF LITERATURE AND CONCEPTUAL FRAMEWORK}

\section{Literature Review}

In 2001, theministry of education conducted a study and ascertains that the level of academic stress in first year students of Nigeria Universities, bad condition of student housing facility was found to be one of the major causes of stress among university students. (Aluko, 2011).

It further revealed a very high level of perceived academic stress among first year undergraduates in Nigerian Federal Universities which are dependent on the inadequate provision of facilities in the students' hall of resident. Consequently, students' housing facilities are seriously inadequate and the available one is in deplorable condition. Student housing is becoming one of the most important industries that produce job opportunities according to a new research report by the National Multi Housing Council (NMHC). The analysis of over 2000 privately owned properties shows that students' housing is a potential one in creative market job that could help the industry counteracts the effect of rising home ownership rate.

During the design process of human shelter, certain determinants deserve consideration, irrespective of prevailing socio-economic condition and attendants, materials and technologies. To this, climate has been considered to be a determinant of building form and of the choice of materials and constructional techniques. Reviewing into the past, many authors have given various ideas about the origin of mass housing for the public and students in higher institution, as regard their important and problems.

Among these are (Onibokun, 1999); (Aluko, 2009); (Burka, 2003). In view of this, one cannot talk about student housing without its maintenance and management aspect, the opinion that housing management like any other business enterprises is concerned with correct motivation of staff and fairness to tenants by consulting, informing and encouraging them so that a sense of partnership and point endeavour are established. Above all, it is necessary or essential that the right kind of organization be put in place by management firms with appropriate built-up fledged housing management department that sees to the co-ordination of elements to be applied in the management decision.

\section{CONCEPTUAL FRAMEWORK}

\section{Housing Concept}

Examining the concept of housing, it is agreed that man's basic needs in life are physiological, which include food, clothing and shelter. The importance of shelter in man's life is second to none but food and clothing. In other words, man seeks protection from the environmental elements only after he has satisfied the need for food and clothing. This assertion was corroborated by Abraham Maslow (1943) in his hierarchy of needs where he identified three fundamental needs crucial to survival, thus food, clothing and shelter. Shelter according to the United Nations, (2007) differs marginally from the concept of housing while housing is widely accepted as being more than mere shelter, housing goes far beyond having a roof over one's head but rather comprises a number of ancillary services and utilities which links the individual and his family to the community and the community to the region in which it grows and progresses.

The need for an effective and conducive student housing facility in an institution cannot be over emphasized due to the fact that students are expected to be in a sound state of mind to excel in their academic endeavors which can only physical protection but also a healthy social and behavioral stability, the productivity of a set of student may not be totally unconnected with their housing condition. 


\section{PRIVATIZATION CONCEPT}

Privatization as a concept is not a new concept, and very little has changed in the concept of privatization from even as far back as the 1930's. Perhaps the biggest single change in the current privatization environment in the area of social and human services is the possibility of private companies being contracted to administer entire public funded system (Nighingale\&pindus, 1997) as cited by (Aluko, 2011). According to the World Bank, privatization "is the transfer of ownership of state owned enterprises (SOEs) to the private sector by sale (full or partial) of going concerns or by sale of assets following their liquidation." It is also the term refers to the shifting of the provisions of service from the government to private sector.

Privatization is a concept whereby government property is transferred to the private, the concept of privatization is broader than that, and it also entails transfer of public functions to private sector. Although privatization can also be diverse, starting from releasedgovernment assets and ending with the state renouncing certain functions and its interference into people's private affairs. ( (Aluko O. , 2011) cited Simasius, 1997).

In Nigeria, there is an increased drive towards privatization of state owned Enterprises. The objectives of the privatization and commercialization programme according to the Director-General Bureau of public Enterprises are to:

- restructure and rationalize the public sector in order to lessen the dominance of unproductive investment in the sector;

- re-orientate the enterprises for privatization and commercialization towards a new horizon of performance improvement, viability and overall efficiency;

- raise funds for financing socioeconomics developments in such area as health, education and infrastructure;

- ensure positive returns on public sector investments in commercialized enterprises, through more efficient management;

- check the present absolute dependence on the Treasury for funding by otherwise commercially oriented parastatals and so, encourage their approach to the Nigeria Capital Market to meet their funding requirements;

- initiate the process of gradual cession to the private sector of such enterprises which are better operated by the private sector;

- Create more jobs, acquire new knowledge and Technology and expose the country to international competition. (Official website of the Embassy of the Federal Republic of Nigeria, Washington DC, 1999).

According to (Simasius, 1997)"It does not necessarily follow that the transfer of state owned property to private hands proclaims the pursuit of free market principle" It is an important to private government functions, such as social security and education. The success of privatization will, to a great extent depends on the suitability of its mechanism. The concept of privatization in this research project gains its relevance from the recent thrust of the Federal Government of Nigeria towards privatization of its facilities including student housing in University of Lagos.

\section{STUDENTS' HALL OF RESIDENT AT OBAFEMIAWOLOWO UNIVERSITY, ILE- IFE}

ObafemiAwolowo University, Ile- Ife, is one of Nigeria first generation universities founded by the (Western Region Government) now owned by the federal government and is situated in Nigeria's peri-urban area in Osun State. The institution is provided with student accommodation facilities even though that was not the right original intent. It was mainly conceived as a university expected to provide tuition to a non-residential student population. However, factors like high rent, cost of transportation and traffic have led to a review of the policy by the university administration. The University can only accommodate about 10,000 students (extracted from ObafemiAwolowo University, Ile- Ife website). The allocation into various students of housing is as follows: first year students, final year students, foreign student, sportsmen and women. These include virtually all overseas students who applied for accommodation in the university. Nevertheless, both residential and nonresidential students enjoy common on campus facilities of catering, sports and recreation, club and association and health services.Due to the fact that not all students are provided for in terms of accommodation and that not all of them would rather stay within the campus, a lot of alternative arrangement have been provided or made, some by the students themselves and others by private organization. Some of these arrangements include boys quarters within the staff quarters exclusive hotels in the vicinity of the school premises. The student housing is run solely by the ObafemiAwolowo University, Ile- Ife governing body. Initially a government subvention was received and used for the management of these residents through the fees contributed by the students. These fees come to an amount of about (3090 for fresher and 2590 for staylite) for a bed space in a dormitory room (ObafemiAwolowo University, Ile- IfeStudents' Affairs Office). 


\begin{tabular}{|c|c|c|}
\hline Table 1A: List Students' Hall & \multicolumn{2}{|l|}{} \\
\hline Name of Students' Hall of Resident at OAU, Ile - Ife & \multicolumn{2}{|l|}{} \\
\hline MuritalaMuhammed & Post-Graduate & \\
\hline Awolowo Hall & Under-graduate & \\
\hline Fajuyi Hall & Under-graduate & \\
\hline LadokeAkintola Hall & Under-graduate & \\
\hline Angola Hall & Under-graduate & \\
\hline Mozambiq Hall & Under-graduate & \\
\hline Aluminal Hall & Under-graduate & \\
\hline Education Trust Fund Hall & Under-graduate & \\
\hline Moremi Hall & Under-graduate & \\
\hline Source: Directorate of Students' Affairs, OAU, (2015) \\
\hline
\end{tabular}

\section{MATERIALS AND METHODS}

The sources of data consist of both primary and secondary data. The primary data made use of the personal interview: oral or verbal interview, administration of the questionnaire after the reconnaissance survey of the study area. The questionnaires were issued to the students' only. The questionnaire issued to the students' was based on how they examine the hall condition in term of causes and effect of deterioration of infrastructure and facilities within the hall of the resident. The essence of distributing the questionnaire to the students' is to avoid being bias in order to have an objective analysis. While the secondary data were obtained from extensive literature review of relevant seminar paper, reports, journals, textbooks, newspapers, and maps relevant to the study.The total number of students hostels is nine and questionnaires were administered in each of the hall base on the number room per hall (see table 1B) and a total of 270 questionnaire was administered among students' in all hall of resident.

\begin{tabular}{|l|l|l|}
\hline \multicolumn{3}{|c|}{ Table 1B: Breaking down of Questionnaire Per Hall } \\
\hline Hall Name & Total Block & $\begin{array}{l}\text { Questionnaire } \\
\text { per Hall }\end{array}$ \\
\hline MuritalaMuhammed & 8 & 20 \\
\hline Awolowo Hall & 16 & 50 \\
\hline Fajuyi Hall & 12 & 30 \\
\hline LadokeAkintola Hall & 12 & 30 \\
\hline Angola Hall & 18 & 40 \\
\hline Mozambiq Hall & 22 & 40 \\
\hline Aluminal Hall & 4 & 10 \\
\hline Education Trust Fund Hall & 6 & 20 \\
\hline Moremi Hall & 12 & 30 \\
\hline Total & $\mathbf{1 1 0}$ & $\mathbf{2 7 0}$ \\
\hline
\end{tabular}

The University has an estimated students' population of about 31,000 out of which about $45 \%$, which are 13,950 students' of the population live in the hall. On the basis of this, about $1.9 \%$ of those students reside in hall were interviewed. The method used in administering the questionnaire is the simple systematic random sample, whereby students in every three room interval were interviewed in each of the students' hall, on this basis, two hundreds and seventy questionnaires in all was administered in all student' hall in the study area. The data collected was analyzed using descriptive techniques such as tables, percentages, and one way ANOVA.

VIII. DATA ANALYSIS AND DISCUSSIONS

On the socio-economic characteristics of the respondents, there are more male students compare to the female out of the population sampled with $5.6 \%$ male and $44.4 \%$ female, the reason being that there are varieties of private female hall within the campus which were built through public private means. This trend may last for some time if the pattern in the institution persists. The age structure as in table 1 shows that $14.8 \%$ were below 17 years, $26 \%$ were between the ages of 18-20 years, 37.4\% were between $21-23$ years, $18.5 \%$ were between 24-27 years, and $3.7 \%$ were above 28 years and above. The proven that the university follows the age limit as set by Nigerian university commission. The results also show that $56 \%$ of the students are illegal occupier of the bed spaces (squatters) while $44 \%$ are permitted occupier. 
The implication of too many squatters is that the facilities are over stretched. The rooms are overcrowded and there is a lack of privacy. The result is that as the general problems perceived by the students with a lack of privacy were unclean environment 68.5 , loss of belonging $53.7 \%$

\begin{tabular}{|c|c|c|c|}
\hline Variable & & Frequency & Percent \% \\
\hline & Male & 150 & 55.6 \\
\hline \multirow[t]{2}{*}{ Gender } & Female & 120 & 44.4 \\
\hline & & 270 & 100 \\
\hline \multirow[t]{4}{*}{ Region } & North & 20 & 7.4 \\
\hline & East & 50 & 18.5 \\
\hline & West & 200 & 74.1 \\
\hline & & 270 & 100 \\
\hline \multirow{10}{*}{ Hall } & Awo & 60 & 22.2 \\
\hline & Faj & 50 & 18.5 \\
\hline & Etf & 20 & 7.4 \\
\hline & Moz & 20 & 7.4 \\
\hline & Moremi & 50 & 18.5 \\
\hline & Alumi & 20 & 7.4 \\
\hline & Angola & 20 & 7.4 \\
\hline & $P, g$ & 20 & 7.4 \\
\hline & Akintola & 10 & 3.7 \\
\hline & & 270 & 100 \\
\hline \multirow[t]{6}{*}{ current part } & 1 & 20 & 7.4 \\
\hline & 2 & 50 & 18.5 \\
\hline & 3 & 60 & 22.2 \\
\hline & 4 & 130 & 48.1 \\
\hline & 5 & 10 & 3.7 \\
\hline & & 270 & 100 \\
\hline \multirow[t]{5}{*}{ length of stayed } & 1 & 60 & 22.2 \\
\hline & 2 & 100 & 37 \\
\hline & 3 & 80 & 29.6 \\
\hline & 4 & 30 & 11.1 \\
\hline & & 270 & 100 \\
\hline \multirow[t]{20}{*}{ Income per week } & 400 & 1 & 0.4 \\
\hline & 900 & 1 & 0.4 \\
\hline & 1000 & 7 & 2.6 \\
\hline & 1500 & 1 & 0.4 \\
\hline & 2000 & 13 & 4.8 \\
\hline & 2500 & 9 & 3.3 \\
\hline & 3000 & 16 & 5.9 \\
\hline & 4000 & 27 & 10 \\
\hline & 5000 & 40 & 14.8 \\
\hline & 6000 & 1 & 0.4 \\
\hline & 8000 & 9 & 3.3 \\
\hline & 9000 & 9 & 3.3 \\
\hline & 10000 & 37 & 13.7 \\
\hline & 12000 & 18 & 6.7 \\
\hline & 15000 & 18 & 6.7 \\
\hline & 17500 & 9 & 3.3 \\
\hline & 20000 & 27 & 10 \\
\hline & 24000 & 9 & 3.3 \\
\hline & 30000 & 18 & 6.7 \\
\hline & & 270 & 100 \\
\hline \multirow[t]{3}{*}{ Legal Occupant } & Yes & 150 & 55.6 \\
\hline & No & 120 & 44.4 \\
\hline & & 270 & 100 \\
\hline
\end{tabular}




\begin{tabular}{|l|l|l|l|}
\hline Age & 2 & 10 & 3.7 \\
\hline & 3 & 10 & 3.7 \\
\hline & 17 & 20 & 7.4 \\
\hline & 18 & 30 & 11.1 \\
\hline & 20 & 40 & 14.8 \\
\hline & 21 & 20 & 7.4 \\
\hline & 22 & 50 & 18.5 \\
\hline & 23 & 30 & 11.1 \\
\hline & 24 & 20 & 7.4 \\
\hline & 25 & 20 & 7.4 \\
\hline & 27 & 10 & 3.7 \\
\hline Total & 28 & 10 & 3.7 \\
\hline source: field survey, July, 2015 & $\mathbf{2 7 0}$ & $\mathbf{1 0 0}$ \\
\hline
\end{tabular}

On the assessment of the students hall facilities condition, the study reveals that the student housing in ObafemiAwolowo University, Ile-Ife has more than average number of the total facilities in deteriorating conditions, where $54 \%$ of respondents' strongly agreed that water closet is bad, $54.4 \%$ and $38.9 \%$ respectively agree that water closet and bathroom were bad, $39.3 \%$ window/door, $22.6 \%$ agreed that electric appliance were bad, electric appliance, $64.6 \%$ bathroom bad, kitchen $70.4 \%$ and $70.4 \%$ for refuse disposal. The implication of this is that if the poor facilities in the hall are not put in the proper place or repaired. More damage will occur and the students' life will be prone to danger/ endangered. (Plate1 \& 2 below show the physical condition buildings, room, toilet, and bathroom in students' hall of resident in OAU, Ile-Ife).
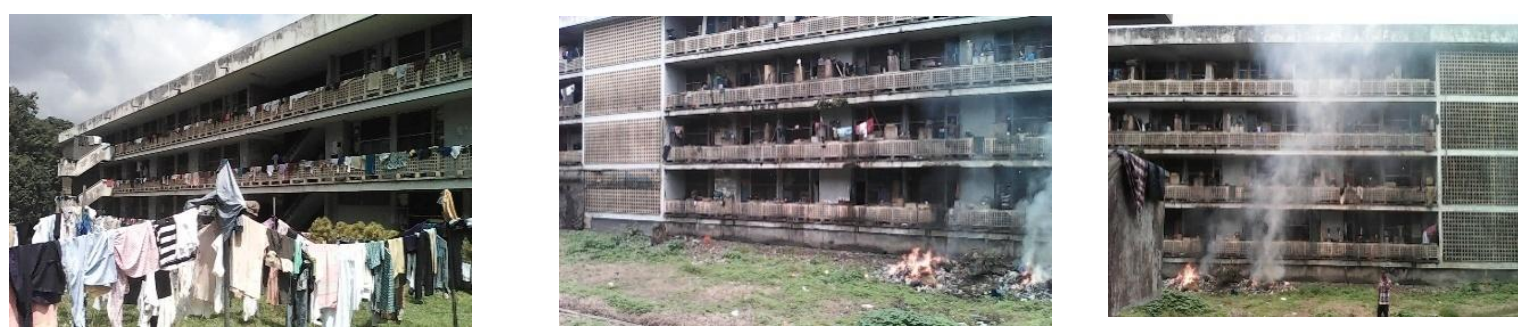

Plate 1: Physical conditions of hall of resident in the study area

Source: Researcher field survey, 2015

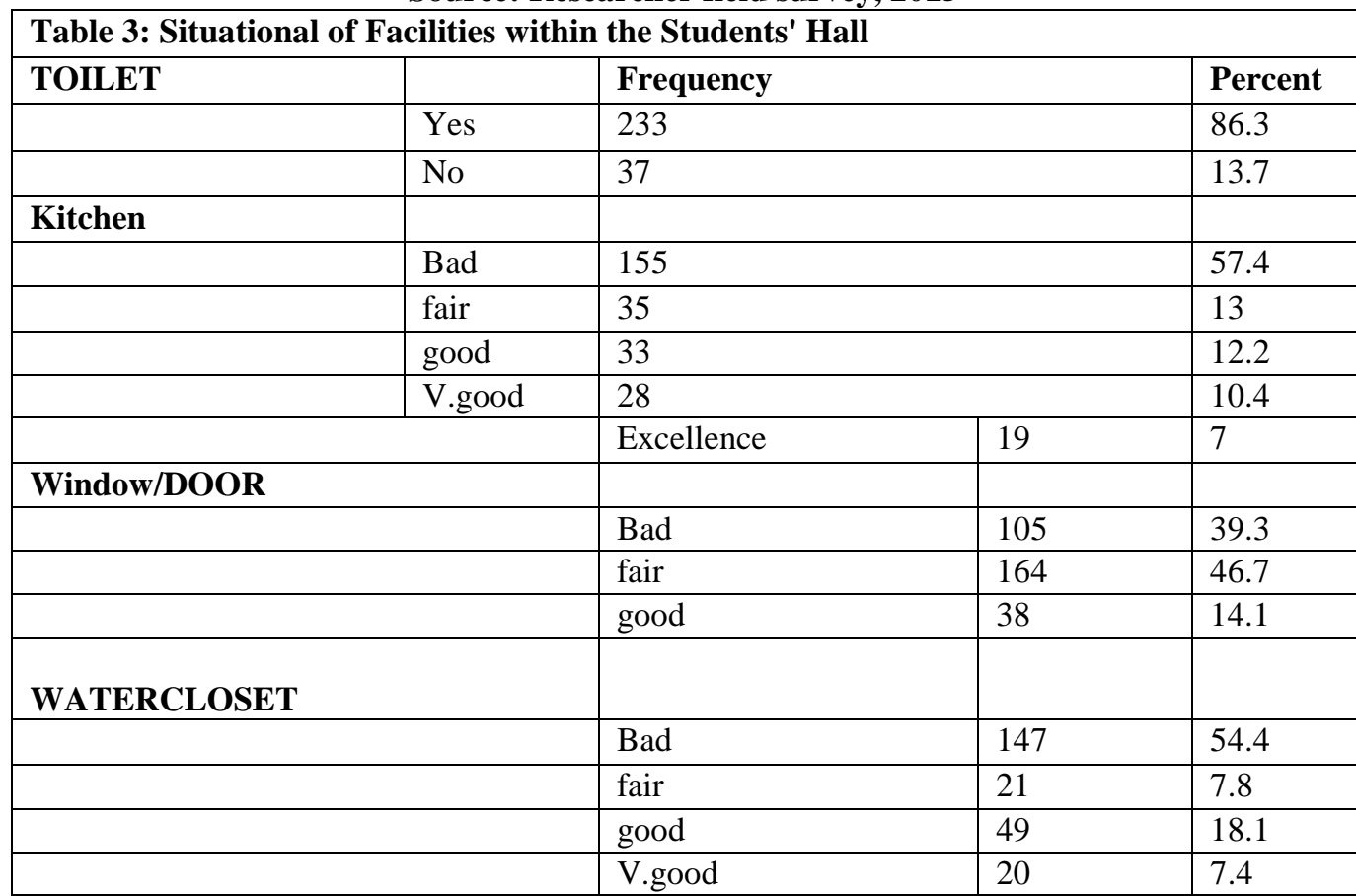




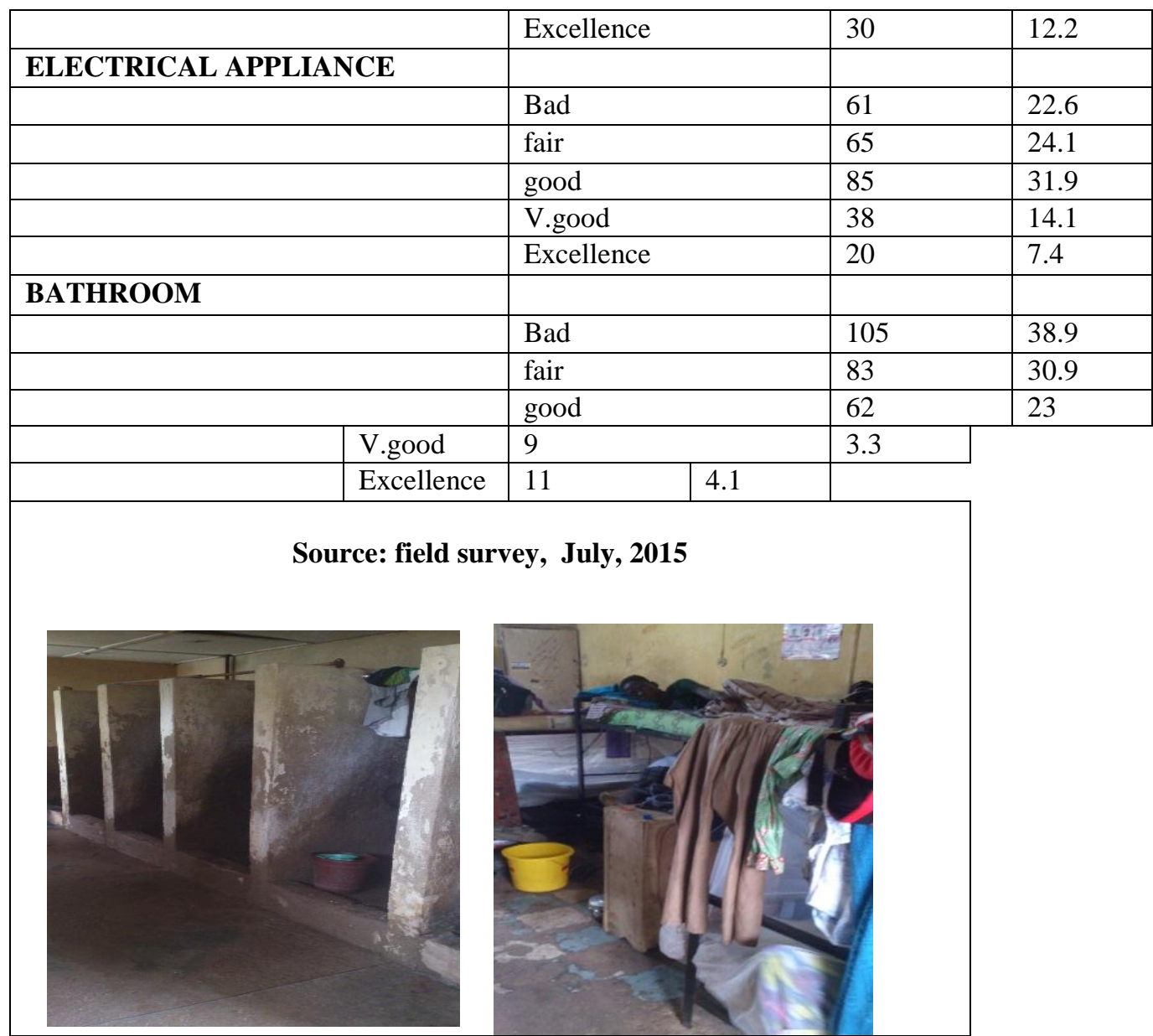

Plate 2: The present conditions of room, toilet and bathroom within students' hall of resident in $O A U$ Source: field survey, 2015

The basic infrastructure like water supply, refuse disposal and building condition was examined. This is done to determine the cleanliness of the water supply is in the study area and how clean it is. $53.7 \%$ of the respondents strongly do not agree that water is clean and potable for drinking. $60.4 \%$ of respondents' agreed the deterioration was due to lack of regular maintenance while $72.6 \%$ agreed that lack of maintenance has caused structural defect of the building. This indicates that there are inconsistencies in the operational activities of the students' hall management section.

\begin{tabular}{|l|l|l|}
\hline \multicolumn{2}{|l|}{ Table 4: Causes/Effect of Deterioration on Hall } \\
\hline Cleanliness & frequency & percent \\
\hline strongly disagree & 145 & 53.7 \\
\hline disagree & 125 & 46.3 \\
\hline Causes Deterioration & 163 \\
\hline lack of maintenance & 16 & 60.4 \\
\hline students' background & 73 & 5.9 \\
\hline Hall shortage & 18 & 27 \\
\hline mis-management & 6.7 \\
\hline Effect Of Deterioration & 196 & \\
\hline structural defect & 65 & 72.6 \\
\hline academic & 1 & 24.1 \\
\hline students' behaviour & 3.3 \\
\hline Source: field survey, July, 2015 & \\
\hline
\end{tabular}


ANOVA

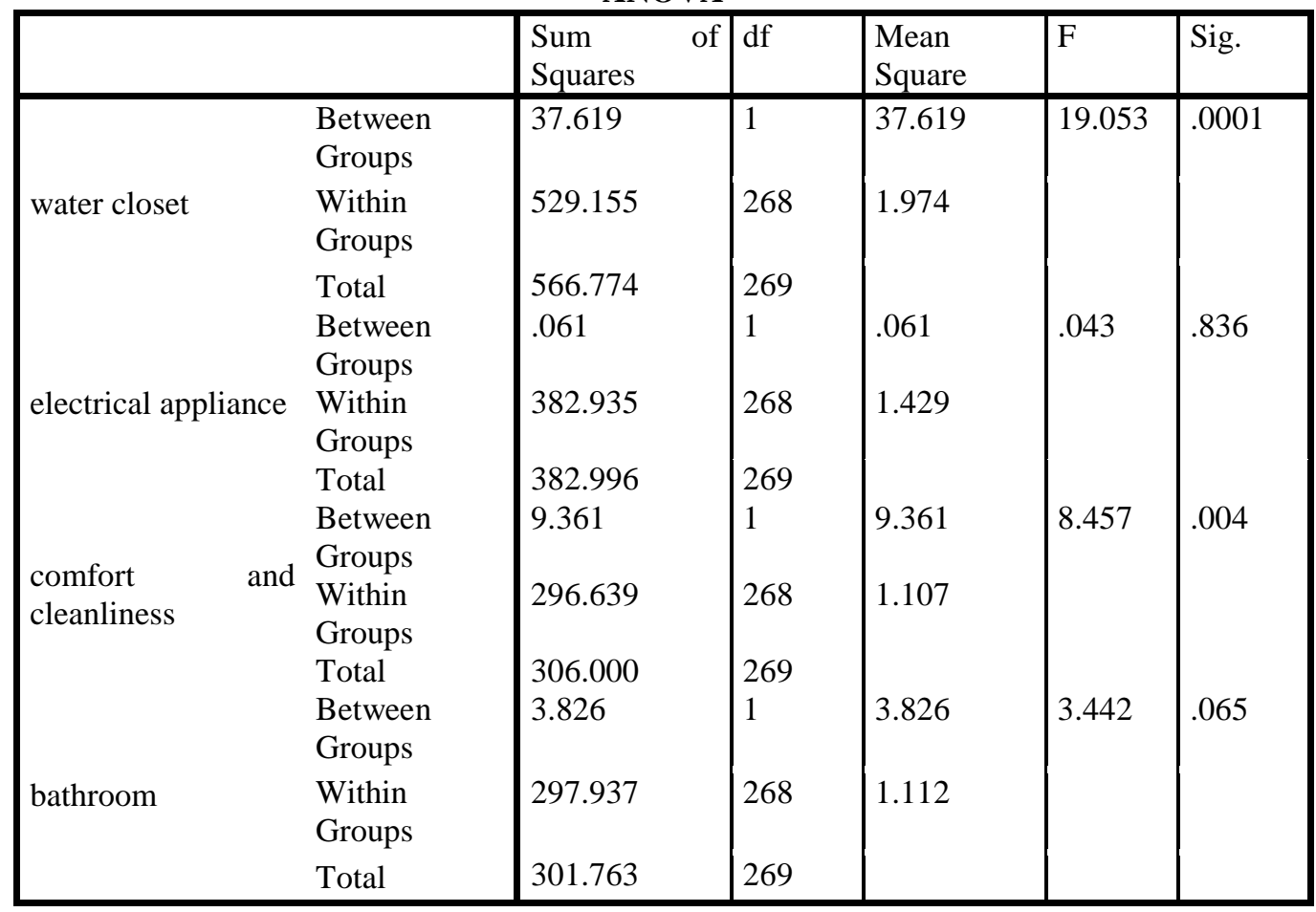

The one way ANOVAreviewed that there is significant relation between fees pay by students' on their accommodation and facilities such as bathroom, comfort and cleanliness, water closet and electric appliance within the students'hall of resident in ObafemiAwolowo university, Ile-Ife, (.0001, .836, .004 and .065) respectively.

\section{SUMMARY OF FINDINGS}

With all the problems identified, ranging from bad state of the facilities, poor maintenance, overcrowding in hall, illegal squatter among others, the following findings were identified from the study area: The survey carried out shows that the condition of students in the hall of resident is in poor state. The condition

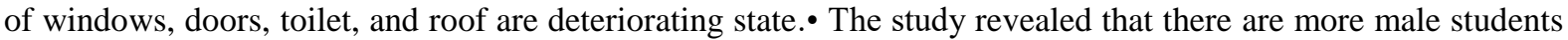
staying in the hostel compared to their female counterparts. This opposed the study of (Aluko, 2011) that more female were staying in the hall of resident more than male. As a result of inadequacy of the existing accommodation, coupled with high rate of illegal squatters that is 8-16/16-24 students' living in a room and the recommended maximum is meant to be six (6) and twelve (12) students respectively per room (from the manual for space standards and use of allocation by Vagale). The hostel utilities and services are therefore over utilized which lead to deterioration of the hall. The initial objective of safety in the hostels as regard nearness and to avoid lateness to classrooms seems to have been neglected. This could be attributed to queue in the morning for the use of bathrooms. See (plate 1, 2 and table 2,3).

\section{RECOMMENDATIONS}

With reference to socio-economic characteristics analyses and survey carried out on the existing condition of the study area, coupled with the summary of the findings from the data analysis, the existing housing facilities needs to be rehabilitated, this involve improving the condition of the existing utilities and services that are in state of dis-repair. And more facilities should be offered within the hall ranging from toilet, bathroom, re-wiring of all room for safety purposes, and drinkable water supply for the students.

In order to meet up with the number of students admitted every year, it is recommended that the institution authority builds more hostels for the students. The stipulated number of a person in lieu of the existing British Standards of occupancy ratio is two (2) people per room and not more than four (4) people in a room. It is recommended that this standard should be followed, and planning regulations should be instituted in order to set the minimum possible standard for a building to be used as a student's hall of resident.

University management should enter into a partnership with private entrepreneurs in the student housing construction venture like Build, Operate and Transfer(BOT) where initial funding and management are left to the private hands and adequate supervision made by the university management. The university authority 
should endeavor to engage facility manager to manage the students' hall of resident for the purpose of sustainability.

\section{CONCLUSION}

The study has shown that the ObafemiAwolowo University, with policies on housing condition have both high and low points, the only way to achieve a habitable, good condition and functionality in students' hall was tore-tightening the portal system in all the hall of residence in the institution. Because housing condition dictate students' performance. Also there is need to provide housing for all the admitted students' in the University, this should be addressed as a matter of urgent interest. Since the institution is the most beautiful chosen as the first choice university of all candidates, that is "the first choice and the most preferred university in Nigeria.

\section{REFERENCE}

[1] Aluko, O. (2009). Housing and Urban Development in Nigeria,. Ibadan: Kins, Publisher.

[2] Aluko, O. (2011). The Assessment of Housing Situation among Students in the University of Lagos. An International Multi-Disciplinary Journal, Ethiopia, 5(3), 104-118.

[3] Arima, B. (1992). An Empirical Analysis of the Demand for Housing Attributes in a Third World City. Land Economics., 68(4), 366.

[4] Badmus, A. S., Olabode, B. O., \& Adebayo, T. A. (2014). Housing and national development: the Nigerian experience. Journal of Social Sciences and Public Policy,, 6(2), 21-28.

[5] Burka, M. (2003). The Increment of Tuition and Accommodation Fees in Nigerian University: A Systematic Disempowerment". Zaria, Nigeria.: Ahmadu Bello University Press,.

[6] Directoriate of Students' Affairs, (2014/2015). Student Handbook. Ile-Ife: Obafemi Awolowo University Press.

[7] Jiboye, A. (2011). sustainable Development through Effective Housing Delivery Process in Nigeria. African Journal of Social Sciences, 1(2), 36-45.

[8] Nega, J. (2014). Situational Assessment of Off-Campus Resident Female Students of Jimma Teacher Training College (Jttc) In Focus, Oromia. European Scientific Journal, 10(32), 238-250.

[9] Omeife, C. (2012, july 31). Let's give new housing policies a chance. Retrieved from The Vanguard News Papers,: http://www.vangardngr.com/2012/07/lets-give-new-housing-policy-a-chance

[10] Omole, F. (2001). Basic issues in Housing Development. Akure Ondo State: Femobless Publication.

[11] Onibokun, P. (1999). Housing in the Nigeria. Ibadan: Nigeria Institute of Socio Economic Research.

[12] Report of the UN World commission on Development and Environment. (1987). Our Common Future. Brundfland Report.

[13] Robinson, R. (1979). Housing Economics and Public Policy. London: The Macmillan Press Ltd.

[14] Simasius, R. (1997). Privatization will Liberate Human Initiative to work efficiently. The Free Market", 4.

[15] The Federal Government Of Nigeria. (1996). National Housing Policy. Abuja: Publication of Federal Government of Nigeria.

[16] Ugonabo,U., C.,\& Emoh, F. I., (2013). The Major Challenges To Housing Development And Delivery In Anambra State Of Nigeria. Civil and Environmental Research, 3(4), 1-19.

[17] Ukwayi, K., J., Eja,E. E.,Ojong,F. E.,\& Out, J. E., (2012). An Assessment of Housing Delivery in Nigeria: Federal Mortgage Bank Scenario. Canadian Social Science, 8(6), 68-74.

[18] UN-Habitat. (2007). Milestones in the Evolution of Human Settlement Policies. 1976-2006. State of the World Cities. Report 2006/2007. The MDGS and Urban Sustainability. 30 years of Shaping the Habitat Agenda. Earsthean: UN-Habitat. 